\title{
Assessment of Health Issues that Encountered by Street Children in
}

\author{
Kirkuk City
}

\section{Nazar Ahmed Mahmood*}

\begin{abstract}
Background and aim: Street children used to refer to children who experience homelessness and live on streets. They are the most vulnerable group to political and economic changes. We conducted this study to assess the health problems that face street children in Kirkuk city as well as identify demographic characteristics of those children.

Material and method: A cross-sectional survey was conducted from June $1^{\text {st }}, 2014$ to April $1^{\text {st }}$, 2015 in Kirkuk-Iraq. Data were collected in various settings including markets, streets, playgrounds, etc., we selected a convenient sample of 150 children and conducted questionnaire to reach the purpose of the study. Data analysis was done via using descriptive statistics, which included frequency and percentages. Results: The findings of the study show that $50 \%$ of the children are at age 16 to 20 years of which, $80.7 \%$ were male, and $58 \%$ of them were refugees. Because of their being street children, poverty constitutes $81.3 \%$. $50.7 \%$ of the children was selling wares, $59.3 \%$ of them had faced maltreatment, and $54.3 \%$ of the children had received treatment for headache. Poverty, low income, was the main reason that led children to work in streets because most of them were refugees.
\end{abstract}

Conclusions: The children were mainly suffering from headache and back pain.

Recommendation: this paper focuses mainly on basic needs as well as assets to minimize risk factors to the lowest extent possible.

Keywords: Street children, Poverty, Refugees.

\section{INTRODUCTION}

The most vulnerable group to political and economic changes is children, especially at the state and community level as they cannot react to and interact with these changes in a way that adults can. That is because children need to be taken care of by adults so that they grow physically, develop their personality, progress, and have good health. However, for many reasons, a huge number of children populations of the world are not taken care of by adults. Hence, the majority of these children are obliged to live on streets (De Benitez, 1997).

Street children used to refer to children who experience homelessness and live on streets. On the other hand, Homeless youth are often called street kids and/or street youth. The definition of street children is controversial, in spite of that, United Nations Children's Fund (UNICEF) concept is used by many practitioners and policymakers. "Any boy and girl, was taken the street as a source of livelihood without care or protection or supervision by officials adults" (United Nations Children's Fund (UNICEF), 2012).

The World Health organization classifies street children according to four categories: first children who reside on street, second children who leave their families and live on street, hotels, shelters, or abandoned places, third children who live at protection centers or orphanages, who are at risk of becoming homeless, fourth children who have weak or insubstantial relations with their families whose circumstances force them to spend nights outside their homes. These children live in transiting life style and are susceptible to risk factors including inadequate nutrition, physical injuries, substance use, and sexual and reproductive health problems. These factors diminish the effectiveness of activities which direct street children. Street children are affected by many common diseases such as tuberculosis, skin diseases, dental problems, and parasitic diseases. However, these diseases can be prevented by providing basic needs and resources (World Health Organization (WHO), 1995). Street children are constantly increasing worldwide (De Benitez, 2011). They have been greatly increasing in Iraq since the U.S.-led occupation began in 2003. According to the NGO Coordination Committee in Iraq (NCCI) (Amit Pyakurel , 2007), the main reason for this behind this huge increase in number of street children is the deteriorating economic condition of the country. This study was conducted in Kirkuk City for many reasons including lack of

* Lecturer / College of Nursing / University of Kirkuk 
specialized studies on issues of street children in Iraq, lack of accurate statistics on the problem size, scarcity of data on the characteristics of children in streets situation (i.e., how they spend their time, why they remain in the streets), neglecting these children, and prevalence of street children phenomenon in the above mentioned city. So that, this study is conducted to assess the health problems that face street children in Kirkuk city as well as identify demographic characteristics of those children and to explore some factors of the presence of street children in Kirkuk city.

\section{MATERIALS AND METHOD}

To achieve the objectives of the study, a cross-sectional survey was conducted for ten consecutive months from June 1st, 2014 to April 1st, 2015. The current study was conducted in Kirkuk city which is located in north of Iraq. Data were collected from various settings (locations) including markets, streets, playgrounds, parking, workplace, and abandoned structure. These settings were chosen because of the expected high concentration of street children. The cross-sectional survey was carried out by means of convenience sampling, (i.e. all children who were present at the time of conducting the survey were invited to participate). Even though 180 children were invited to participate in the survey; however, 150 of them agreed to enroll in the study. All participants were informed that their personal information are preserved and the responses they provide remain anonymous. A questionnaire was constructed to reach the purpose of the study. The instrument of the study was based on the extensive review of related literature and studies (WHO, 2000; Peter et. al., 2011) after making adjustments on the instrument to comply with the cultural reality of Iraqi people. The data was collected by using personal and interview techniques. The questionnaire consisted of five parts, demographic data which is composed of 7 items, conditions of housing and access to basic utilities which is composed of 2 items, involvement of street children in economic activities which is composed of 3 items, difficulties and hazards which is composed of 2 items, and health issues that encountered by the children which is composed of 14 health issues. A panel of 8 experts was involved in the determination of the questionnaire content validity. The questionnaire was pilot tested on 10 students to test the readability of the instrument and ease and clarity in answering the survey questions. Participants of the pilot study were not involved in the final study. Data were analyzed by using descriptive statistics, which included frequency and percentage. The data then were prepared, organized and entered into computer files through a known statistical program named Statistical Package for Social Science (SPSS) version 19

\section{RESULTS}

( Note: for some items the respondent answered more than one)

Table (1): distribution of the study sample (N= 150) according to socio-demographic characteristic of Street Children.

\begin{tabular}{|c|c|c|}
\hline \multirow{2}{*}{ Characteristics } & Frequency & Percent \\
\hline & $\mathbf{F}$ & $\%$ \\
\hline \multicolumn{3}{|l|}{ Age (Years) } \\
\hline$(<5) \quad$ years & 2 & 1.3 \\
\hline (6-10) years & 15 & 10 \\
\hline$(11-15)$ years & 58 & 38.7 \\
\hline (16-20) years & 75 & $\mathbf{5 0}$ \\
\hline Total & 150 & 100 \\
\hline \multicolumn{3}{|l|}{ Gender } \\
\hline Male & 121 & 80.7 \\
\hline Female & 29 & 19.3 \\
\hline Total & 150 & 100 \\
\hline \multicolumn{3}{|l|}{ Category of Street Child } \\
\hline Children of the street & 10 & 6.7 \\
\hline Children on the street & 137 & 91.3 \\
\hline Home and street & 3 & 2 \\
\hline Total & 150 & 100 \\
\hline \multicolumn{3}{|l|}{ Current residence } \\
\hline From city & 63 & 42.0 \\
\hline Refugees & 87 & $\mathbf{5 8 . 0}$ \\
\hline Total & 150 & 100 \\
\hline \multicolumn{3}{|c|}{ The Family Situation of the children } \\
\hline Both parents alive & 101 & 67.3 \\
\hline Mother alive, father dead & 26 & 17.3 \\
\hline Father alive, mother dead & 8 & 5.3 \\
\hline Both Parents dead & 15 & 10 \\
\hline Total & 150 & 100 \\
\hline \multicolumn{3}{|c|}{ The persons who working in the family } \\
\hline Father & 39 & 26 \\
\hline Mother & 28 & 18.7 \\
\hline Father and mother & 2 & 1.3 \\
\hline Brothers and sisters & 144 & 96 \\
\hline \multicolumn{3}{|c|}{ The Reasons for Being Street Children } \\
\hline Parents passed away & 16 & 10.7 \\
\hline Family problems & 16 & 10.7 \\
\hline Does not want to & 1 & 0,7 \\
\hline Poverty & 122 & 81.3 \\
\hline Lack of parental care & 8 & 5.3 \\
\hline
\end{tabular}


Table (2): Distribution of the study sample $(\mathrm{N}=150)$ according to conditions of housing and access to basic utilities

\begin{tabular}{||l|c|c|}
\hline The Places of living & Frequency $(f)$ & Percentage (\%) \\
\hline Charitable institutions & 3 & 2 \\
\hline In the street & 1 & 0.7 \\
\hline In a mobile house & 11 & 7.3 \\
\hline In a deserted building & 17 & 11.3 \\
\hline Rental house & $\mathbf{1 1 8}$ & $\mathbf{7 8 . 7}$ \\
\hline $\begin{array}{l}\text { Availability of basic utilities within places where the } \\
\text { children live }\end{array}$ & Frequency $(\boldsymbol{f})$ & Percentage (\%) \\
\hline Toilet, water system and electricity & $\mathbf{5 3}$ & $\mathbf{3 5 . 3}$ \\
\hline Toilet, water only & 14 & 9.3 \\
\hline Toilet and electricity only & 27 & 18 \\
\hline Toilet only & 2 & 1.3 \\
\hline Water system and electricity only & 2 & 1.3 \\
\hline Water system only & 2 & 1.3 \\
\hline \hline
\end{tabular}

Table (3): Distribution of the study sample ( $N=150)$ according to Involvement of street children in economic activities

\begin{tabular}{|l|c|c||}
\hline Economic Activities of Street Children & Frequency & Percentage \\
\hline Begging & 31 & 20.7 \\
\hline Guarding Cars & 18 & 12 \\
\hline Washing Cars & 12 & 8 \\
\hline Selling Wares & $\mathbf{7 6}$ & $\mathbf{5 0 . 7}$ \\
\hline Others & 13 & 8.7 \\
\hline Total & $\mathbf{1 5 0}$ & $\mathbf{1 0 0}$ \\
\hline Level of satisfaction by the street children with the work they do & Frequency & Percentage \\
\hline Totally satisfied & 52 & 34.7 \\
\hline Somewhat satisfied & 52 & 34.7 \\
\hline Not satisfied at all & 46 & 30.6 \\
\hline Total & $\mathbf{1 5 0}$ & $\mathbf{1 0 0}$ \\
\hline
\end{tabular}

Table (4): Distribution of the study sample ( $N=150)$ according to Difficulties and hazards

\begin{tabular}{|l|c|c||}
\hline Difficulties and hazards encountered by the street children: & Frequency & Percentage \\
\hline Facing difficulties/maltreatment & $\mathbf{8 9}$ & $\mathbf{5 9 . 3}$ \\
\hline Not facing difficulties/maltreatment & 61 & 40.7 \\
\hline Total & $\mathbf{1 5 0}$ & $\mathbf{1 0 0}$ \\
\hline Types of difficulties faced by street children: & Frequency & Percentage \\
\hline Violence & 36 & 24 \\
\hline People mockery & $\mathbf{4 3}$ & $\mathbf{2 8 . 7}$ \\
\hline Health problems & 3 & 2 \\
\hline Stresses & 2 & 1.3 \\
\hline Weather conditions & 1 & 0.7 \\
\hline Others & 3 & 2 \\
\hline
\end{tabular}

Table (5): Distribution of the study sample $(\mathrm{N}=150)$ according to health issues that encountered by them

\begin{tabular}{|l|c|c|}
\hline $\begin{array}{l}\text { Children who received treatment for the various disease symptoms } \\
\text { they may have had }\end{array}$ & Frequency & Percentage \\
\hline Headache & $\mathbf{6 8}$ & $\mathbf{5 4 . 3}$ \\
\hline Chest pain & 4 & 2.7 \\
\hline Abdominal & 19 & 12.7 \\
\hline
\end{tabular}




\begin{tabular}{|l|c|c|}
\hline Renal & 21 & 14 \\
\hline Back pain & 46 & 30.7 \\
\hline Shortening breath & 6 & 4 \\
\hline Cough & 5 & 3.3 \\
\hline Dental & 28 & 18.7 \\
\hline Ear & 1 & 0.7 \\
\hline Skin Diseases & 5 & 3.3 \\
\hline Gastric & 17 & 11.3 \\
\hline Asthmatic & 21 & 14 \\
\hline Intestinal & 1 & 0.7 \\
\hline Hair Lice & 7 & 4.7 \\
\hline Other diseases & 3 & 2 \\
\hline
\end{tabular}

\section{DISCUSSION}

Table (1) shows that half (50\%) of study sample at age group (16-20) year, while the lowest percentage $(13 \%)$ their ages lower than $(<5)$ years, $(80.7 \%)$ of the study sample were males, majority of them $(91.3 \%)$ of them were children on the street and (58\%) of the study sample were refugees. The findings also show that $(67.3 \%)$ of both children's parent were alive, while $(10 \%)$ of them both their parents were dead. Concerning the persons who working in the family, brothers and sisters constitute the majority of them (96.0\%), poverty constitute $(81.3 \%)$ as a reasons for being street children. The findings of table (2) shows that most of children $(78.7 \%)$ were live in a rental house, only $(35.3 \%)$ of the children live in a house with basic utilities like Toilet, water system and electricity. The findings of table (3) shows that the around half $(50.7 \%)$ of sample was selling wares followed by $(20.7 \%)$ of begging. (30.6\%) of children were not satisfied at all with the work they do. The findings of table (4) shows that $(59.3 \%)$ of children had faced maltreatment, (28.7\%) of those were people mockery followed by $(24 \%)$ with violence. The findings of table (5) shows that $(54.3 \%)$ of children had received treatment for headache, $(30.7 \%)$ of them for back pain, (18.7\%) of them for dental problems followed by (14\%) for renal problems.

The ongoing wars and blockade conditions have influenced the Iraqi society and its social composition in which hundreds of thousands of fathers have involved in the army and larger number of them have martyred and captured. These situations had significant impact on household incomes. The absence of fathers' role in families, which raised many family wise problems, reflected on child-rearing, loss of selfesteem and confidence of others, and sense of exposure to harm which forced many children to work and as a result leaded to spread of the phenomenon of street children. In the current study, most of the specified street children were within 16-20 years old. This indicates that majority of the samples were young adults. The tasks of this age of people should focus on completing preparation for life's work, internalizing a belief system, finding meaning of life, participating in community (Peter et. al., 2011; Clark, 2014). However, this age group is deprived of these activities as a result of nonstable conditions through which Iraq has passed. In the developing countries, WHO put a proportion of girls among street children to be less than 30\% (WHO, 2000). The current study reported the same proportion of girls as recorded by WHO. Furthermore, a similar finding was reported from the Lusaka study which puts the proportion of girls at 20\% (Project Concern, 2002). This could be attributing to the social and cultural composition of Iraqi people, where girls are not allowed to work on streets and their work is limited to domestic works. Majority of children spent most of their time in the street, but who regularly go back to their homes at night. Contrary to that, a study in Zimbabwe conducted by UNICEF (2001), showed that the majority of the street children interviewed were children "of the street", who worked and slept on the streets. This may be explained by the fact that most of these children work because there is no enough food at home. More than half of street children were refugees probably reflecting the observation of Uvin (1998) who noticed that number of street children may increase with the existence of violence. In current study refugees were included as part of the surveyed children. The reason behind that is that many refugees fled to Kirkuk in summer of 2014, when the Islamic State (IS) occupied most of Iraq's Sunni areas, resulting in a population increase in tens 
of thousands who fled during the country's sectarian war in the period from 2005 to 2008 .

Almost about two-thirds of the children were living with both parents. The determination of street children status is not just related to time on the streets, it also has a very vital family and collegial component as suggested by Naterer and Godina (2011). Moreover, the findings of their study that conducted in Makeevka, indicate that the majority of street children had two living parents, but that their parents did not have lot of authority over them. This indicated that there is no relationship between the absence of one or both parents and the presence of children in the streets. Street children pointed out a number of reasons for being on the streets including parents' death, family problems, and lack of parental care. Nevertheless, poverty appeared to be the basic reason in pushing children onto the streets. This could be attributed to the insufficient economic situation experienced by children as a result of their displacement to Kirkuk. The result of the present study is consistent with findings in the literature (Iqbal, 2005). The findings disclosed that majority of children live in rental houses and small number of these houses contained basic resources such as toilet, water and electricity system. Most of the children were living in non-hygienic conditions that may affect directly or indirectly the psychological and physical health aspect for children which in turn expose them to health problems. Richard et. al. (1994) noticed similar factors in his study thereby predisposing street children that are vulnerable to health problems. Such problems could be reduced or solved by providing street children houses with appropriate resources and assets. Vendor like selling wares, tissues, plastic bag, etc., are the most prominent activities that children were involved in because of poverty which comes out as the most prominent reason for the children being involved in economic activities. This is in accordance with Peter et. al. (2011) findings. Begging comes out as the second activity by street children because most of the children were young and they are more successful in arousing the compassion of local residents (Quiterie et. al., 2012). About one-third of the children were not satisfied with the work they do. The reason behind this could be the society's perception, they believe that the society has a negative perception towards them (i.e., they perceive that society disrespects them as a result of the type of work they do). The findings of the study also revealed that more than half of the children faced different types of difficulties during their presence in the streets. The difficulty which more frequently faced them was people mockery followed by violence and robberies. In a similar study conducted in Palestine, the authors reported that street children expose to numerous problems and difficulties during their presence in the street including physical and psychological abuse (Defence for Children International (DCI), 2007). Many children in street mainly suffer from headache and back pain which made them take treatment for reducing consequences. In contrast, Peter et. al. (2011) pointed out that most of the children in streets received treatment for fever and cough. This variation could be related to many influences such as genetic and ethnic factors, inactive lifestyles, and incorrect dietary habits. Moreover, the data collection of the current study has compiled in a season as fever and cough are rarely prevalent. Furthermore, other health issues has registered in street children for the present study including dental problems, asthma, abdominal and gastric problems, hair lice, breath shortness, and ear problems respectively. It is a usual findings because of unhygienic environment (due to lack of basic needs and resources) in which they spend most of their time while they were working in the street.

\section{CONCLUSIONS}

The study concluded that the poverty was the primary reason in pushing children onto the streets; most of these children were refugees. More than half of children faced difficulties during their presence in the streets like people mockery and violence. The children in streets were mainly suffering from headache and back pain.

\section{RECOMMENDATION}

The study recommended providing of basic needs and to minimize the risk factors as much as possible. Furthermore, activating the role of the media to raise awareness of the importance of addressing the problem at an early stage, do not consider these children are as criminals but victims, and they deserve care more than they deserve Conviction.

\section{REFERENCES}

Amit Pyakurel (ammykumars). (2007). OhmyNews. English. [accessed 31 May 2011]. Available from: http://ohmynews.com/ articleview/article_view.asp?at_code= 398032 
Clark, MJ. (2014). Community Health Nursing: Advocacy for Population Health. $\left(5^{\text {th }}\right.$ ed.). united states of America , Pearson. P.p. 333.

De Benitez, S.T. (2007). State of the world's street children: violence. Consortium for street. London: Latimor Trend, Plymouth,

De Benitez, S.T. (2011). State of the world's street children: research. London: Consortium for street children.

Defence for Children International (DCI) Palestine Section. (2007). Children in the Street. The Palestinian Case,. Available from: http://www.dcipal.org/ english/publ/research /2007/ChildrenintheStreetEnglish.pdf.

Iqbal, F. (2005). Literature review on the sexual abuse juvenilej and street children in sindh. Karachi: Social welfare department PCCWD Government of Sindh.

Naterer, A.; and Godina, V. (2011). Bomzhji and their subculture: An anthropolitical study of street children subculture in Makeevka, Eastern Ukraine. Childhood. P.p.1-19.

Peter, FN; Muzzammil, H; Ratish, P. (2011). Operational Study on Street Children in Rodrigues. Available from: http://compnetltd.com/mfpwa/sites/def ault/files/global_funds/ Operationalresearch-Study4Rodrigues-

Streetchildren.

Project Concern. (2002). Rapid assessment of street children in Lusaka: fountain of hope. Flame Jesus Cares Ministry. Lazarus. Zambia;
Quiterie, Pincent.; Hélène, Willart; Marie, Chuberre. (2012). Street Children: from individual care to the introduction of social policies. Delphine Laisney, Technical Resources Coordinator, Samusocial International. Available from: www.afd.fr

Richard, PU.; Lilian, G.; Mary, S.; and Jana, L. (1994). Health care for homeless: A family medicine perspective. $A n$ Family Physician. 49. P.p.139-145.

UNICEF. (2001). A Study on Street Children in Zimbabwe, UNICEF Zimbabwe, in collaboration with the government, donors, and civil society. ZIM. Available from: http://www.unicef.org/ evaldatabase/index 14411.html.

United Nations Children's Fund (UNICEF). (2012). The State of the World's Children. Children in an Urban World. New York: UNICEF.

Uvin, P. (1998). Aiding violence: The development enterprise in Rwanda. Boulder: Kumarian Press. Available from:

http://fletcher.tufts.edu/ /media/Fletch er/Microsites/ praxis/ xv/ Coletta .pdf

World Health Organization (WHO). (1995). Working with street children. WHO/MSD/MDP/00.14.

World Health Organization (WHO). (2000). Working With Street Children: Module 1. A Profile of Street Children. In: Dependence. Geneva: World Health Organization. 